\title{
UK gets the green light on modified crops
}

[LONDON] Opposition in Britain to the genetic modification of agriculture crops has been dealt a major blow by the publication of two potentially influential reports. Both conclude that certain genetically modified crops pose negligible risks to human health and the environment.

The government's Scientific Advisory Committee on Releases to the Environment (ACRE) declared this week that, based on the available evidence, it is safe to plant herbicide-tolerant oilseed rape.

This effectively gives the green light to regulatory authorities in European Union (EU) member states to allow the company Plant Genetic Systems (PGS) to market its modified oilseed rape. It will also ease the way for a similar application from the company AgrEvo.

The decision comes on the heels of a report published last week of a House of Lords inquiry into the European Community's system of regulating genetic modification in agriculture. The report opposes calls for a moratorium on the commercialization of genetically modified crops.

The inquiry agreed with government proposals to assess potential risks simultaneously with the growth of crops on a commercial scale. It also concluded that unnecessary delays to commercialization could harm the agriculture industry.

The report also calls for a swift end to the use of antibiotic marker genes, and adds that EU countries should be allowed to opt out of growing genetically modified crops. This is a response to those states, notably France, that oppose genetic modification.

Last week, 100 food writers joined the campaign against genetically modified food. But with these exceptions, opponents of genetically modified crops in Britain are running out of formal options for delaying their introduction.

Some see their last chance in an ongoing government review of scientific advisory committees involved in biotechnology regulation. But this review is unlikely to lead to radical changes to present policy.

ACRE's decision on the oilseed rape was not unanimous. The dissenter was Julie Hill of the Green Alliance, the only member from an environmentalist group.

She argues that while scientists currently have no evidence that genes transferring from modified crops cause harm, such a scenario cannot be ruled out. "We should do more to understand the long-term impacts before proceeding," she says.

Critics of the Lords report include English Nature, the government's wildlife and countryside advisory body. In a strongly worded statement, the organization said the Lords committee has "completely failed to grasp that applying broad-spectrum herbicides to herbicide-tolerant crops during the growing season will give many more farmers the power to remove all weeds from fields, putting yet more pressure on our already beleaguered wildlife".

The PGS application to market its oilseed rape in EU countries has been held up by objections from France over the possibility that rape genes might transfer to its weedy relatives, thereby conferring herbicide tolerance on the weeds.

ACRE's advice is based on a 63-page review of research on gene transfer from oilseed rape that has been genetically modified to tolerate the herbicide glufosinate. The review was carried out by Alan Gray, head of the Institute of Terrestrial Ecology, and a member of the committee.

Gray concludes that no further evidence has emerged since PGS's initial application in 1994 to suggest that modified oilseed rape is more weedy or invasive than unmodified varieties. Similarly, he says that the risk of genes from herbicide-tolerant rape leading to a proliferation of herbicide-tolerant weedy relatives remains very small.

But Gray says genetic modification in agriculture will not be decided solely on scientific criteria. "Scientists forget that there is an ethical dimension to this," he says. "As a scientist, I find the idea of 'genetic pollution' difficult. But whether we have the moral right to put [introduced genes] into nature is not a scientific question." EhsanMasood

\section{Hopes for reform rise as Spain replaces its hard-line minister}

[BARCELONA] The Spanish government last week dismissed the Minister of Education and Culture, Esperanza Aguirre, a member of the conservative wing of the ruling 'Partido Popular' party, in a move warmly welcomed in educational circles.

Aguirre had been criticized for her apparent obstinacy in promoting the teaching of humanistic subjects such as history and philosophy in schools at the expense of biology and geology, as well as for her support for privatizing education.

In addition, her failure to establish effective dialogue with universities and teaching organizations has been blamed for delays in changing the laws on university administration, and for difficulties in decentralizing various educational matters.

Last month, for example, Aguirre angered regional educational departments and school officials by attempting to introduce significant reforms throughout Spanish schools just before various educational responsibilities were transferred to the six autonomous regions.

This move was immediately opposed by the Official College of Spanish Geologists,

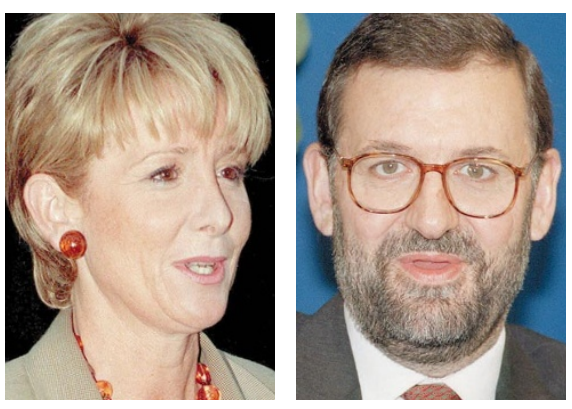

Aguirre (left) hands over to 'pragmatic' Rajoy.

which described the two subjects as "fundamental for the general training of anyone, not just those wanting to specialize in science in the future".

Aguirre's replacement, Mariano Rajoy, a 43-year-old lawyer, has been enthusiastically endorsed by her critics. Widely considered as pragmatic and open-minded, Rajoy's main handicap may be a lack of familiarity with the education world.

In addition to Aguirre's unpopularity, the reason for the change of minister is said to have been a tactical move by the Partido Popular in the light of the imminent local and regional elections, as well as the government party's general congress of. Also, Rajoy's politics are close to those of prime minister José Maria Aznar, whereas Aguirre is a liberal.

The new minister has already announced a reorganization of the ministry. The previous departments of school education, universities and research have been placed in a single State Office of Education, to be headed by Jorge Fernández Díaz.

Rajoy's appointment has pleased Spain's vice-chancellors. Saturnino de la Plaza, vicechancellor of the Polytechnic University of Madrid and president of the Spanish Universities Vice-chancellors Conference, says that the vice-chancellors' first discussion with Rajoy will concern the situation of more than 20,000 university professors employed on short-term contracts.

As for the creation of a single office covering all levels of education, de la Plaza says "the existence of one only state office should not have any negative repercussions, as long as university and research issues are properly managed".

Xavier Bosch 